\title{
Biculturalism: What Could it Mean in Education in Aotearoa New Zealand?
}

New Zealand Journal of Teachers' Work, Volume 15, Issue 1, 24-27, 2018

\author{
MEGAN LOURIE \\ Auckland University of Technology
}

In a recent article 'Early Childhood Education and Biculturalism: Definitions and Implications', Chris Jenkin (2017) sets out to explore definitions of biculturalism and advocates for a shift to using the term 'Tiriti-based practice' in education. Jenkin concludes that this approach better captures ideas of partnership and power sharing between Māori and non-Māori, reflecting the intention of the Treaty of Waitangi. As Georgina Stewart points out in her response to Jenkin's article (in this isue), however, a change in name does little to address the problem of a fundamental lack of understanding of biculturalism. A 'Tiriti-based' practice, as far as clarity of the term goes, seems likely to be no less contested or slippery in meaning than biculturalism. Instead, Stewart suggests "rebooting" the concept of biculturalism, "which in its radical form has the capacity to act as an educational concept for society and the educational system". Unfortunately she goes no further in terms of explaining how this radical form might be understood, but does remind us that in New Zealand there are two peoples in existence with intertwined intellectual and sociolopolitical histories. That fact in itself, I believe, provides sufficient grounds to encourage educators to continue to grapple with the concept of biculturalism, and indeed, to 'reboot' our understandings so that they reflect our experiences and aspirations in the complex messiness of education in the 21st century.

Both Chris Jenkin and Georgina Stewart are clearly of the view that the concept of biculturalism could and should reflect something valuable and intrinsically vital to Aotearoa New Zealand and I agree. My point of divergence from my colleagues' perspectives is that I believe it is time to stop looking backwards in time for explanations or definitions to clarify the concept, whether it be in policy documents or the archives, and to begin to imagine and explore what it could be. This is not to suggest that we should ignore the past, but rather to use our understandings of how the concept of biculturalism has been understood, and how it is currently given expression in education settings, to inform our thinking about what biculturalism could mean.

I have two main reasons for advancing this argument. The first is that attempting to find clear, agreed-upon definitions of biculturalism in education policy is a fruitless task (Jenkins, 2017; Lourie, 2013; 2015; 2016). While it is quite common for biculturalism to be acknowledged in policy documents, the term bicultural itself is not defined or explained. For example, the New Zealand Curriculum "acknowledges the principles of the Treaty of Waitangi and the bicultural foundations of Aotearoa New Zealand" (Ministry of Education, 2007, 
p. 9), but provides no further guidance about how the term bicultural is to be understood. Perhaps more surprising, given its claim to be the first bicultural curriculum, is the absence of a definition of biculturalism in New Zealand's ECE curriculum Te Whariki (Ministry of Education, 2017, cited by Jenkin, 2017). To some extent, this reflects the nature of policy itself. As Ball (2017) reminds us, we often overestimate the logical rationality of policy, whereas in reality policy is frequently "messy, contradictory, confused and unclear" (p. 11). Another characteristic of policy is that it is better understood as an ongoing, interactional process by which a set of ideas or a discourse is constantly being reworked over time, often via texts which accompany policy documents (Ball, 2017). This means, that in terms of understanding biculturalism in educational contexts, the various reports, strategies and initiatives which give expression to biculturalism, give us a better sense of how the concept is currently interpreted and enacted.

This latter point brings me to the second reason I am proposing that it is time for a substantial 'reboot' of biculturalism without necessarily being constrained by past understandings or interpretations. Contemporary education initiatives and strategies such as Ka Hikitia - Accelerating Success 2013-2017 (Ministry of Education, 2013) and Tātaiako: Cultural Competencies for Teachers of Māori Learners (Ministry of Education, 2011), are based on a narrow interpretation of biculturalism which promotes a focus on the strengthening and affirming of Māori cultural identity. A great deal appears to ride on the assumption that acknowledging and including the cultural identity of Māori students will lead to improved academic achievement as claimed in $\mathrm{Ka}$ Hikitia; "[w]e know Māori students do much better when education reflects and values their identity, language and culture (Ministry of Education, 2013, p. 6). Elsewhere I have argued that biculturalism is assumed to address the problem of monoculturalism in New Zealand schools (Lourie, 2016). Monoculturalism, or the lack of acceptance of ethnic and cultural difference, tends to be the dominant explanation for the underachievement of Māori students, so much emphasis has been placed on the responsibility teachers have for developing and enacting culturally responsive pedagogy. Unfortunately, despite nearly forty years of bicultural education policy, which has resulted in greater visibility and inclusion of Māori culture in education settings, there is still an achievement gap between Māori students and their non-Māori peers.

In advocating for an alternative to the term biculturalism, Jenkin draws attention to issues of power-sharing between Māori and non-Māori. It seems to me that notions of power-sharing are difficult to enact in a meaningful way in education settings if socio-economic explanations for the underachievement of Māori students are essentially bracketed out of discussions. The current dominant approach, which focuses on the way a student's culture is acknowledged and included in the classroom, makes it very difficult for teachers to include beyond-school factors when considering underachievement without being accused of 'deficit-theorising' (Bishop \& Glynn, 1999). If, however, we are going to agree that power-sharing is, or should be, a core principle of biculturalism, then greater attention needs to be paid to the economic and social policies that embed wider inequalities into New Zealand society.

In addition, taking the notion of power-sharing in education settings seriously demands that we pay closer attention to contemporary questions about the changing relationships between education, curriculum and access to different types of knowledge. For example, while the National Certificate in 
Educational Achievement (NCEA) offers multiple pathways for students to gain qualifications, and this has resulted in a larger percentage of Māori students gaining Level 2 NCEA (Ministry of Education, 2018), there have been questions raised about the types of courses Māori students have gained their credits from. For example, a New Zealand Herald investigation reported disparities hidden beneath rising rates of success at secondary schools tied to students' socioeconomic status and ethnicity. A blunt summary of the findings of the investigation reads "while wealthy white students study science and Shakespeare, their poorer brown peers are more likely to be learning to make coffee or operate a grill" (Johnston, 2016).

There is much to be gained from rebooting biculturalism even if it means being in a relationship that Stewart aptly describes as, at times, unsettling and uncomfortable. If, however, we are to advocate for a different kind of relationship, the kind that Jenkin is suggesting which addresses the issue of unequal power relations between Māori and the Crown, we have to be prepared to tolerate discomfort as we embark on a "collaborative exploration of the edges of knowledge" (Stewart, 2018, p. 22), and, perhaps even more importantly, to think unfettered beyond the narrow interpretations of biculturalism that are currently enacted in educational settings. 


\section{REFERENCES}

Ball, S. (2017). The Education debate (3rd ed.). Bristol, Enhland: Policy Press.

Bishop, R., \& Glynn, T. (1999). Culture counts: Changing power relations in education. Palmerston North, New Zealand: Dunmore Press.

Jenkin, C. (2017). Early Childhood Education and biculturalism: Definitions and implications. New Zealand Journal of Teachers' Work, 14(1), 8-20. https://doi.org/10.24135/teacherswork.v14i1.100

Johnston, K. (26 September 2016). Revealed: What's beneath rising NCEA pass rates. New Zealand Herald. Retrieved from www.nzherald.co.nz/nz/news/article.cfm?c id=1\&objectid=11713953

Lourie, M. (2013). Symbolic policy: A study of biculturalism and Māori language education in New Zealand (Unpublished doctoral thesis, University of Auckland, Auckland, New Zealand). Retrieved from https://researchspace.auckland.ac.nz/handle/2292/21456

Lourie, M. (2015). Biculturalism in education: Haere whakamua, hoki whakamuri/Going forward, thinking back. New Zealand Journal of Teachers Work. 12(2), 131-148.

Lourie, M. (2016). Bicultural education policy in New Zealand. Journal of Education Policy, 31(5), 637-650.

Ministry of Education. (2007). The New Zealand Curriculum. Wellington: Ministry of Education.Available from http://nzcurriculum.tki.org.nz/TheNew-Zealand-Curriculum

Ministry of Education. (2011). Tātaiako: Cultural competencies for teachers. Retrieved from https://educationcouncil.org.nz/required/Tataiako.pdf

Ministry of Education. (2013). Ka Hikitia - Accelerating Success 2013-2017. Wellington: Ministry of Education. Available from https://www.education.govt.nz/ministry-of-education/overall-strategiesand-policies/the-maori-education-strategy-ka-hikitia-acceleratingsuccess-20132017/

Ministry of Education. (2018). Education Counts: School leavers with NCEA Level 2 or above. Retrieved from https://www.educationcounts.govt.nz/statistics/indicators/main/education -and-learning-outcomes/school leavers with_ncea level_2_or_above

Stewart, G. (2018). Rebooting biculturalism in education in Aotearoa-New Zealand. New Zealand Journal of Teachers' Work, 15(1), 20-23.

The opinions expressed are those of the paper author(s) and not the New Zealand Journal of Teachers' Work. Copyright is held by individual authors but offprints in the published format only may be distributed freely by individuals provided that the source is fully acknowledged. [ISSN-1176-6662] 